\title{
Ortaöğretim Dokuzuncu Sınıf Matematik Ders Kitaplarının Kök Değerler Çerçevesinde İncelenmesi
}

\author{
İbrahim ÇETiN'1, Ahmet MUTLUOĞLU², Derya Özlem YAZLIK³, Ahmet ERDOĞAN ${ }^{4}$
}

\begin{abstract}
Öz: Bu araştırmada, matematik dersi öğretim programında vurgulanan "kök değerlere” ortaöğretim 9. sınıf matematik ders kitaplarında ne sıklıkta ve düzeyde yer verildiğinin belirlenmesi amaçlanmıştır. Bu amaç doğrultusunda araştırma nitel araştırma desenlerinden durum çalışması modeli ile yürütülmüş̧ür. Araştırmanın verileri, Milli Eğitim Bakanlığı Talim Terbiye Kurulu Başkanlığınca okutulması kararlaştırılan iki adet ortaöğretim 9. sınıf matematik ders kitabının doküman incelemesi tekniği ile incelenmesinden elde edilmiştir. Araştırmada elde edilen verilerin analizinde betimsel analiz tekniği kullanılmıştır. Verilerin analizinin çerçevesini, ortaöğretim matematik ders programında yer alan on kök değer oluşturmaktadır. Araştırmanın sonucunda ortaöğretim 9. sınıf matematik ders kitaplarında en çok yardımseverlik ve sorumluluk; en az ise sabır, öz denetim, dürüstlük ve sevgi değerlerine yer verildiği belirlenmiştir. Öğrenme alanlarına göre kök değerlerin yer alma sıklıkları incelendiğinde en fazla "Sayılar ve Cebir" en az da "Geometri" öğrenme alanında yer verildiği sonucuna ulaşılmıştır. Son olarak, incelenen ders kitaplarında değerlerin yer alma düzeylerinin daha çok zayıf düzeyde olduğu tespit edilmiştir.
\end{abstract}

Anahtar Sözcükler: Ders kitabı, Kök değerler, Matematik eğitimi

\section{Mathematics Textbooks in Secondary Education within the Framework of Root Values}

\begin{abstract}
This study aimed to determine to what frequency and to what level the "root values" emphasized in the mathematics curriculumare included in the $9^{\text {th }}$ grade secondary mathematics textbooks. For this purpose, the research was carried out using the case study model, one of the qualitative research designs. The data for the study were obtained by using the document analysis technique to examine two secondary school $9^{\text {th }}$ grade mathematics textbooks, which have been allocated as textbooks by the Board of Education in Ministry of National Education. The descriptive analysis technique, one of the qualitative data analysis techniques, was used in the analysis of the data obtained in the study. The framework for the analysis of the data was the ten root values specified in the secondary school mathematics curriculum. As a result of the research, it was determined that while the values of being helpful and being responsible were the most prominently included in the secondary $9^{\text {th }}$-grade mathematics textbooks, the values of patience, self-control, honesty and love were the least prevalent. When the frequency of inclusion of root values in textbooks according to learning areas was examined, it was concluded that they were most included in the topic of "Numbers and Algebra" and least included in the topic of "Geometry". Finally, it was determined that the values were frequently included in the textbooks examined at a very low level.
\end{abstract}

Keywords: Textbooks, Root values, Mathematics education 
İnsanları kötü davranışlardan alıkoyan ve davranışlarını düzenleyen unsurların başında sahip olduğu değerleri gelmektedir. Bireyin sağlıklı bir yaşam sürdürebilmesi ve yaptığı işlerde başarılı olabilmesi için fiziksel ve zihinsel gelişiminin yanında olumlu değerleri özümseyerek bunlara sahip olması da gerekmektedir (Meydan, 2014). Aksi hâlde bireyin bu yöndeki gelişiminin ihmali, sahip olduğu potansiyelini kullanması önünde bir engel olabilmektedir (Ulusoy ve Dilmaç, 2012). Kişinin bir parçası olduğu toplumla birlikte yaşamasının temeli, sahip olduğu ortak değerlere dayanır. Bireylerin yaşamında bu denli önemli bir yeri olan değerlerin bir kavram olarak çeşitli alanlarda ve bağlamlarda farklı anlamlarda kullanılabildiği görülmektedir. Bir konuşmayı dinlemenin 'değeri', matematikteki bir denklemde bilinmeyenin 'değeri' ya da bir bireyin (ahlaken) 'değeri' kavramın farklı anlamlarda kullanılmasına örnek olarak verilebilir (Kılcan, 2020). Geniş bir kullanım alanına sahip olan değer kavramının çeşitli bilim dallarında da farklı tanımları yapılmıştır (Ulusoy ve Dilmaç, 2012). Sosyal bilimler alanında yapılan tanımlardan birinde Dede (2007: 13) değeri, "en genel anlamda bir davranışın veya düşüncenin kıymeti veya önemi dikkate alınarak yapılan kişisel tercihler veya toplumun bir üyesi olarak bir birey tarafından benimsenen ve izlenen genel amaçlar" olarak tarif etmektedir. Bolay (2007: 14) ise değeri, “insanların değer verdiği ve ulaşmak için peşinden koştuğu, elde etmeyi şiddetle arzu ettiği şeyler" olarak tanımlarken değerlerin insan davranışları üzerinde hâkim ve yönlendirici inançlar olduğuna vurgu yapmaktadır. Türk Dil Kurumu (TDK, 2020) çevrim içi sözlüğünde değer "bir şeyin önemini belirlemeye yarayan soyut ölçü, bir şeyin değdiği karşılık, kıymet" şeklinde tanımlanmaktadır. Ortaöğretim Matematik Dersi Öğretim Programı'nda (MEB, 2018: 15) ise değer kavramı, "temel insani özelliklerimizi oluşturan değerlerimiz, hayatımızın rutin akışında ve karşılaştığımız sorunlarla başa çıkmada eyleme geçmemizi sağlayan kudretin ve gücün kaynağıdır." şeklinde açıklanmaktadır.

Yaşamdaki gelişim ve değişimle birlikte değerler değişiyor olsa da toplum tarafından genel olarak benimsenenler yeni nesillere aktarılırlar (Altun, 2003). Bu değerlerin bireylere kazandırılması amaciyla yürütülen değerler eğitimi ilk olarak ailede başlar ve öğrenim hayatının başlamasıyla birlikte sürece okul da dâhil olur (Bishop, Clarke, Corrigan ve Gunstone, 2006). Üstelik bu süreç, kasıtlı ve planlı bir şekilde yürütülüyor olmasa dahi devam eder. Ancak böylesi bir eğitimin etkisi fark edilmediğinde ya da kontrol altında tutulmadığında, süreç genellikle bireyin yaşamı için yanlış olabilecek değerleri doğru ve geçerli olarak kabul etmesi şeklinde sonuçlanabilmektedir (Hill, 1991; Kılcan'dan aktaran, 2020). Bu sebeple öğrencilerin okullarda yürütülen eğitim-öğretim faaliyetleriyle birlikte olumlu değerleri içselleştirmeleri önemli bir husus olarak karşımıza çıkmaktadır (Altun, 2003). Nitekim öğretim programlarımızda da bu duruma, bireyin eğitim sistemimiz içerisinde çok yönlü olarak geliştirilmesinin ve değerlerle bütünleşmiş bilgi, beceri ve davranış elde etmesinin gerekliliği vurgusuyla dikkat çekilmektedir (MEB, 2018).

Öğretim programları, öğrencilerin zihinsel, bedensel ve duygusal olarak sağlıklı bir şekilde yetişmeleri amacıyla eğitim-öğretim faaliyetlerinin yürütülmesine kılavuzluk eden temel bir kaynaktır. Bu programların nihai hedefleri arasında öğrencilere milli ve manevi değerlerle bütünleşmiş bilgi ve becerilerin kazandırılması önemli bir yer tutmaktadır (MEB, 2018). Değerler eğitiminin bütün eğitimin esas amacı olduğu noktasından hareketle, sürecin yalnız belirli bir ya da birkaç dersin muhteviyatında yürütülmesi şeklindeki bir yaklaşımla değil, tüm öğretim programlarının ayrılmaz bir parçası olarak ele alınması gerektiği temel bir prensip olarak benimsenmiştir (MEB-TTKB, 2017). Buradan hareketle daha önceki öğretim programlarından farklı olarak değerler eğitimi ilk kez içerisinde matematik dersine ait programın da olduğu öğretim programlarının ana odağına alınmıştır (MEB-TTKB, 2017).

Değerlerin birçok türü olması göz önünde bulundurulduğunda bunlar arasında vurgu yapılacak olanların belirlenerek bir tutarlılı̆̆ın sağlanması önemli bir husus olarak karşımıza çıkmaktadır (Sayın, Orbay ve Şam, 2019). Her ne kadar değerler eğitimi için yeterliliği noktasında bazı şüpheler olsa da (Topal, 2019), öğretim programları marifetiyle öğrencilere kazandırılması amaçlanan değerler on ana başlık altında kök değerler adıyla bir araya getirilerek ülke genelinde öğretim noktasında bir tutarlılık sağlanmıştır. Programda öğrencilere kazandırılması amaçlanan bu değerlerin birçok toplum tarafından benimsenen ve uzun zamandır varlığını sürdüren değerler (Topal, 2019) arasında yer aldığı görülmektedir.

Okulun yaşama hazırlıktan öte yaşamın kendisi olduğu gerçeğinden hareketle öğrencilere bu kök değerlerin kazandırılmasının çok boyutlu ve sistemli bir yaklaşımla ele alınması gereken bir süreç olduğu 
söylenebilir. Öğretim programında da değerlerimizin öğrencilere kazandırılmasının ancak eğitim programının tüm unsurlarının (öğretim programı, mevzuat, okul ortamı, ders araç gereçleri vb.) dikkate alınmasıyla gerçekleştirilebileceği vurgulanmaktadır (MEB, 2018). Bu sebeple eğitim programında değerler eğitiminin ayrı bir müfredat veya öğrenme alanı, ünite, konu gibi birimlerde ele alınması olarak değil tüm öğretim programlarında ve bileşenlerinde yer verilmesiyle kazandırılması benimsenmiştir (MEB, 2018). Peki, matematik dersi bu sürecin neresindedir? Matematik değerler eğitiminden bağımsız bir alan mıdır? Şayet değilse bu süreçte matematiğin nasıl bir rolü vardır?

Matematiksel bilginin dünyanın her yerinde aynı ve nesnel olduğu ve esasen bağlamdan ayrı olduğu algısı, yaygın olarak matematiğin kültürden ve değerden bağımsız olarak düşünülmesine sebep olmaktadır (Seah ve Bishop, 2000). Hatta bu durum matematik öğretmenlerinin de matematik dersinde değerlerin öğretilebileceğine karşı zayıf bir inanç taşımalarına sebep olmaktadır (Dede, 2007). Hâlbuki matematik de kendi içerisinde değerler barındırır ve matematik eğitiminde değerlerin kazandırılmasının önemli bir yeri vardır (Bishop, 1999; Dede, 2007). Bu sebeple matematik dersi; öğrencilere öğretim programında yer alan kazanımlara dönük bilgi ve becerileri kazandırmanın yanı sıra; onların millî, manevi ve evrensel değerler bakımından eğitimini de amaçlamaktadır (MEB, 2018). Dersin bu amacına ulaşabilmesi için kullanılan temel kaynaklardan biri de ders kitaplarıdır. Ders kitaplarının her öğretmen ve öğrenciye ulaştırılıyor olması göz önüne alındığında, ortak değerlerin öğrencilere kazandırılmasına kaynaklık eden önemli araçlardan biri olduğu söylenebilir. Nitekim alan yazında bu amacın gerçekleştirilmesine aracılık edebilecek çeşitli kaynakların olduğu ve bunlar arasında öğretim programları ve bu programlara göre hazırlanmış ders kitaplarının önemli bir yerinin olduğu vurgulanmaktadır (Cao, Seah ve Bishop, 2006; Clarkson, FitzSimons ve Seah, 1999; Dede, 2007; Karaca ve Uzunkol, 2019; Şahin ve Başgül, 2018; Şahin ve Ersoy, 2012).

Alan yazın incelendiğinde, matematik ders kitaplarında yer alan değerlerin araştırılmasını konu edinen çalışmaların sınırlı sayıda olduğu göze çarpmaktadır. Bu amaçla yürütülmüş çalışmalara bakıldığında ise ilkokul ve ortaokul düzeyindeki kitapların ele alındığı görülmüştür. Şahin ve Başgül (2018) ortaokulun, Şahin ve Tuğrul (2020) ise ilkokulun farklı sınıf düzeylerinde okutulan matematik ders kitaplarında öğrenme alanlarına göre sosyal değerlere ne sıklıkla ve nasıl yer verildiğini incelemişlerdir. Karaca ve Uzunkol (2019) ilkokul 3. ve 4. sınıf düzeylerinde benzer bir çalışmayı yürütmüş ve incelediği altı matematik ders kitabında on bir farklı değere yer verildiğini tespit etmiştir. Diğer taraftan ders kitaplarında yer alan kök değerlerin araştıııldığı çalışmaların ise yalnız ortaokul düzeyinde gerçekleştirildiği görülmüştür. Yapılan çalışmalarda ortaokul matematik ders kitaplarında kök değerlerin öğrenme alanlarına ve sınıf düzeylerine göre nasıl dağıldığı (Özkaya ve Duru, 2020), bu değerlere kitabın hangi sayfalarında yer verildiği (Kılcan, 2020) ve ünitelere göre değerlerin nasıl dağılıp nasıl ele alındığı (Sayın ve diğerleri, 2019) ortaya konulmuştur.

İlgili alan yazındaki çalışmalara bakıldığında genelde matematik ders kitaplarında hangi değerlere ne sıklıkla yer verildiğinin ve bu değerlerin kitabın hangi bölümünde/öğrenme alanında ele alındığının belirlendiği görülmüştür. Hâlihazırdaki bu çalışmalarda, ders kitaplarında değerlerin dersin içeriğiyle nasıl bütünleştirilerek ele alındığına ya da nasıl bir bağlam içerisinde işlendiğine yönelik tespitlerin eksik kaldığı göze çarpmaktadır. Hâlbuki değerlerin anlamlı ve kalıcı olabilmesi için dersin bağlam ve kazanımları ile bütünleşmiş olması ve yalnız adından söz edilmesi şeklindeki bir yaklaşımdan vazgeçilmesi gerektiği ifade edilmektedir (MEB-TTKB, 2017). Bu anlamda bakıldığında, ders kitaplarda yer alan kök değerlerin ne düzeyde işlendiğini / ele alındığını belirlemeye dönük alan yazında herhangi bir çalışmaya rastlanılmamıştır. Bu noktadan hareketle değerlerin kitaplarda yer alma biçimini ortaya koyması hususunda, değerin gücü ifadesi ihtiyaç duyulan bir kavram olarak bu çalışmada ilk defa araştırmacılar tarafından ortaya konulmuştur. Dolayısıyla çalışmanın yukarıda ifade edilen yönleriyle alan yazına özgün bir katkı sunacağı düşünülmektedir. Ayrıca değerler eğitimine öğretim programlarının tüm unsurları göz önünde bulundurulacak bir şekilde yer alması gerektiği, bu sebeple programların yalnız bir birimiyle (öğrenme alanının, ünite, konu vb.) sınırlı tutulmadan ele alınması gerektiği belirtilmektedir (MEB, 2018). Bu noktadan hareketle çalışmada kök değerlerin, ele alınan ders kitaplarının bölümlerine göre nasıl bir dağılım sergilediği belirlenmiş ve bu anlamda mevcut ders kitapları hakkında bir durum tespiti yapılmıştır. Ayrıca Ortaöğretim Matematik Dersi Öğretim Programında da kök değerlere yer verilmesine karşın bu kademedeki sınıf düzeyleri 
için hazırlanan ders kitaplarının bu kapsamda araştırıldığı herhangi bir çalışmaya rastlanmamıştır. Yukarıda ifade edilen tüm gerekçelerle yapılan bu çalışmanın, alan yazındaki bu açı̆̆ı kapatma noktasında önemli bir katkısının olacağı düşünülmektedir. Yine diğer çalışmalardan farklı olarak bu çalışmanın matematik ders kitaplarında bu değerlerin ne düzeyde ele alındığı hakkında bulgular içermesinden ötürü ilgili alan yazına farklı bir perspektif kazandıracağı düşünülmektedir. Bu amaç doğrultusunda bu çalışmada aşağıdaki sorulara yanıt aranmıştır.

1. Ortaöğretim dokuzuncu sınıf matematik ders kitaplarında kök değerlere ne sıklıkta yer verilmiştir?

2. Ortaöğretim dokuzuncu sınıf matematik ders kitaplarında öğrenme / alt öğrenme alanlarında kök değerlere ne sıklıkla yer verilmiştir?

3. Ortaöğretim dokuzuncu sınıf matematik ders kitaplarının bölümlerinde kök değerlere ne sıklıkla yer verilmiştir?

4. Ortaöğretim dokuzuncu sınıf matematik ders kitaplarında kök değerlere ne düzeyde yer verilmiştir?

\section{Yöntem}

Bu bölümde araştırmanın yöntemi hakkında bilgilere yer verilmiştir. Bu bilgiler araştırmanın modeli ve deseni, verilerin toplanması, verilerin analizi ve geçerlik ve güvenirlik başlıkları altında sunulmuştur.

\section{Araştırmanın Modeli ve Deseni}

Bu araştırmada, matematik öğretim programlarında vurgulanan "kök değerlere" ortaöğretim dokuzuncu sınıf matematik ders kitaplarında ne ölçüde yer verildiğini belirlemek amacıyla nitel araştırma desenlerinden birisi olan durum çalışması kullanılmıştır. Durum çalışması deseninde ele alınan durumlar; kişiler, gruplar olabildiği gibi kitaplar, öğretim programları, davranışlar veya olaylar da olabilir (Creswell, 2012; Neuman, 2014; Yin, 2011). Bu araştırmanın durumunu ise ortaöğretim dokuzuncu sınıf matematik ders kitaplarında yer alan "kök değerler" oluşturmaktadır.

\section{Çalışma Grubu}

$\mathrm{Bu}$ araştırmanın veri kaynağı ders kitaplarından oluşmaktadır. Ders kitaplarının seçilmesinde amaçlı örnekleme yöntemlerinden ölçüt örnekleme yöntemi kullanılmıştır. Araştırmadaki bu ölçüt dokuzuncu sınıf düzeyi olarak belirlenmiştir. Çalışmada, Milli Eğitim Bakanlığı Talim Terbiye Kurulu Başkanlığınca (MEB, 2018) ders kitabı olarak okutulması kararlaştırılan ve www.eba.gov.tr adresinde yer alan iki adet ortaöğretim dokuzuncu sınıf matematik ders kitabı incelenmiştir. İncelenen bu iki kitabın bilgilerine kaynakçanın sonunda yer verilmiştir. 9. sınıf düzeyinde matematik dersinin zorunlu ortak dersler arasında yer alması nedeniyle bu sınıf düzeyindeki kitaplar çeşitli türde ortaöğretim kurumlarına devam eden tüm öğrencilere hitap etmektedir. Bu nedenle kök değerlerin dokuzuncu sınıf düzeyinde incelenmesinin önemli olduğu düşünülmektedir. Ayrıca dokuzuncu sınıfın ortaokuldan liseye geçişte köprü görevi görmesi bu sınıf düzeyindeki kitapların tercih edilmesinin bir başka nedeni olmuştur.

\section{Verilerin Toplanması}

Araştırmanın verileri doküman incelemesi tekniği ile toplanmıştır. Doküman incelemesi tekniğinde, amaç doğrultusunda veri elde edilmesine imkân sunan yazılı, sözlü ve görsel materyaller kullanılabilir (Bogdan ve Biklen, 1992; McMillian ve Schumacher, 2010). Çalışmada ilk olarak www.eba.gov.tr adresinde yer alan iki adet ortaöğretim dokuzuncu sınıf matematik ders kitabı A ve B olarak kodlanarak pdf formatında bilgisayar ortamına aktarılmıştır. Daha sonra bilgisayar ortamına aktarılan kitaplar, sayfa sayısına göre dörder bölüme ayrılarak araştırmacılara dağıtılmıştır. Her bir bölüm ikişer araştırmacı tarafından incelenmiştir. Ortaöğretim matematik dersi öğretim programında belirtilen on adet kök değer ders kitaplarında araştırılmaya başlanmış; rastlanan kök değerin kitapta yer aldığı bölüm, öğrenme alanı, sayfası, kök değerin adı, değere yer verilme düzeyi ve ekran görüntüsü elektronik tablolama programına aktarılmıştır. 


\section{Verilerin Analizi}

Araştırmada ortaöğretim dokuzuncu sınıf matematik ders kitaplarında var olan kök değerlerin analiz edilmesi için nitel veri analiz tekniklerinden betimsel analiz tekniği kullanılmıştır. Betimsel analiz tekniğinde, elde edilen veriler daha önceden belirlenen tema ve kodlara göre yorumlanır. Yine, verilerin elde edildiği kaynaklardan doğrudan alıntılara yer verilebilir (Yıldırım ve Şimşek, 2018).

İncelenen kitaplarda hangi durumların ne şekilde analiz edildiğinin daha iyi anlaşılması adına Tablo 1'de araştırmanın veri analiz çerçevesine ait inceleme örneğine yer verilmiştir.

Tablo 1. Araştırmanın Veri Analiz Çerçevesine Ait Örnek

\begin{tabular}{|c|c|c|c|c|c|c|}
\hline Kitapta Yer Alan ifade & $\begin{array}{l}\text { Kitapta Yer } \\
\text { Aldığı Bölüm }\end{array}$ & \multicolumn{2}{|c|}{$\begin{array}{l}\text { Öğrenme Alanı / } \\
\text { Alt Öğrenme Alanı }\end{array}$} & Kodlayıcılar & Kök Değer & $\begin{array}{c}\text { Değere Yer } \\
\text { Verilme } \\
\text { Düzeyi }\end{array}$ \\
\hline $\begin{array}{l}\text { Kenar uzunlukları birer tam sayı ve } \\
\text { çevresi } 30 \mathrm{~m} \text { olan dik üçgen } \\
\text { şeklindeki bir bahçenin en uzun } \\
\text { kenarı boyunca birer metre } \\
\text { aralıklarla fidan dikilecektir. En } \\
\text { uzun kenarın diğer kenarlarla } \\
\text { kesiştiği noktalara da fidan } \\
\text { dikileceğine göre kaç fidana ihtiyaç } \\
\text { vardır? }\end{array}$ & Hazırlık & Geometri & Üçgenler & Kodlayıcı 1 & Sevgi & Zayıf \\
\hline $\begin{array}{l}\text { • p: “Batuhan evinde boşa yanan } \\
\text { lambayı söndürdü." } \\
\text { • q: “Batuhan parasından tasarruf } \\
\text { etti." } \\
\text { Yukarıda verilen önermelere göre } \\
\text { p } \Rightarrow \text { q önermesini yazınız. }\end{array}$ & Örnek & $\begin{array}{l}\text { Sayılar } \\
\text { Ve Cebir }\end{array}$ & Mantık & Kodlayıcı 1 & Sorumluluk & Orta \\
\hline $\begin{array}{l}\text { Su tasarrufu ile ilgili aşağıdaki } \\
\text { bilgiler verilmiştir. } \\
\text { - Diş fırçalarken musluk sürekli } \\
\text { açık tutulmazsa kişi başı yılda } \\
\text { ortalama } 12 \text { ton, } \\
\text { - Duş süresi } 1 \text { dakika azaltılırsa } \\
\text { kişi başı yılda ortalama } 18 \text { ton, } \\
\text { - } 4 \text { kişilik bir ailede bulaşı ve } \\
\text { çamaşır makinede yıkanırsa } \\
\text { yılda ortalama } 40 \text { ton, } \\
\text { - } 4 \text { kişilik bir ailede sebze ve } \\
\text { meyveler çeşme altında değil de } \\
\text { su dolu bir kapta yıkanırsa yılda } \\
\text { ortalama } 18 \text { ton su tasarrufu } \\
\text { yapılabilmektedir. } \\
\text { Bu bilgilere göre } 4 \text { kişilik bir ailenin } \\
\text { her bireyi, yukarıdaki tedbirleri } \\
\text { uygulamaya başlıyor. } 1 \text { ton } 2,5 \text { Türk } \\
\text { lirası olduğu bir şehirde bu ailenin } \\
\text { bir yıl içerisinde kaç Türk lirası } \\
\text { tasarruf edebileceğini hesaplayıp } \\
\text { verilen her maddeye göre elde edilen } \\
\text { yıllık tasarruf tutarını Türk lirası } \\
\text { cinsinden sütun grafiğiile gösteriniz. }\end{array}$ & $\begin{array}{l}\text { Değerlendir- } \\
\text { me Sorusu }\end{array}$ & $\begin{array}{l}\text { Veri, } \\
\text { Sayma } \\
\text { Ve } \\
\text { Olasıllk }\end{array}$ & Veri & Kodlayıcı 1 & Sorumluluk & Güçlü \\
\hline $\begin{array}{l}\text { Torunlarıla vakit geçirmeyi seven } \\
\text { Hüseyin dede yaşları } 6,8 \text { ve } 12 \text { olan } \\
\text { üç torununa bahçesinden topladığı }\end{array}$ & Örnek & $\begin{array}{l}\text { Sayılar ve } \\
\text { Cebir }\end{array}$ & $\begin{array}{l}\text { Denklem ve } \\
\text { Eşitsizlikler }\end{array}$ & Kodlayıcı 1 & Sevgi & Orta \\
\hline
\end{tabular}




\begin{tabular}{|c|c|c|c|}
\hline $\begin{array}{l}45 \text { tane cevizi yaşlarıyla ters orantılı } \\
\text { olacak şekilde dağıtıyor. Torunların } \\
\text { aldıkları ceviz sayıları dairesel bir } \\
\text { grafikle gösterilirse ortanca torunun } \\
\text { aldığı ceviz miktarını gösteren daire } \\
\text { diliminin merkez açısının kaç derece } \\
\text { olacağını bulup aldığı payı daire } \\
\text { grafiği ile gösteriniz }\end{array}$ & Kodlayıcı 2 & Sevgi & Güçlü \\
\hline
\end{tabular}

Tablo 1'de görüldüğü gibi ortaöğretim dokuzuncu sınıf matematik ders kitabında yer alan değerlerle ilgili ifadeler; kitapta yer aldığı bölüm, öğrenme alanı / alt öğrenme alanı (Mantık, Kümeler, Denklemler ve Eşitsizlikler, Üçgenler, Veri), kök değerler ve değerin gücü başlıklarında iki ayrı kodlayıcı tarafından bağımsız bir biçimde incelenmiştir. Değerlerin kitaplarda yer aldığı bölüm adları, kitapların tanıtım sayfalarında veriliş şekillerine uygun olarak giriş bölümü, bilgi kutusu, örnek, alıştırma ve değerlendirme sorusu şeklinde kullanılmıştır. İncelenen kök değerler, güncel ortaöğretim matematik dersi öğretim programında belirtilen on adet kök değer çerçevesinde ele alınmıştır (MEB, 2018). Bu kök değerler sırasıyla; adalet, dostluk, dürüstlük, öz denetim, sabır, saygı, sevgi, sorumluluk, vatanseverlik ve yardımseverlik şeklinde olup kök değerler ve bu kök değerlere ilişkin tutum ve davranışlar Tablo 2'de verilmiştir (MEB-TTKB, 2017).

Tablo 2. Kök Değerler ve Kök Değerlere İlişkin Tutum ve Davranışlar

\begin{tabular}{|c|c|}
\hline Değerler & Değerlere İlişkin Bazı Tutum ve Davranışlar \\
\hline Adalet & Adil olma, eşit davranma, paylaşma, ... \\
\hline Dostluk & Diğerkâmlık, güven duyma, anlayışlı olma, dayanışma, sadık olma, vefalı olma, yardımlaşma, ... \\
\hline Dürüstlük & $\begin{array}{l}\text { Açık ve anlaşılır olma, doğru sözlü olma, düzgün ve istikrarlı olma, güvenilir olma, sözünde durma, } \\
\text {... }\end{array}$ \\
\hline Öz denetim & $\begin{array}{l}\text { Davranışlarını kontrol etme, davranışlarının sorumluluğunu üstlenme, öz güven sahibi olma, } \\
\text { gerektiğinde özür dileme, ... }\end{array}$ \\
\hline Sabir & Azimli olma, tahammül etme, beklemeyi bilme, dirençli ve dayanaklı olma, sebatkâr olma, ... \\
\hline Sayg1 & $\begin{array}{l}\text { Alçak gönüllü olma, başkalarının kendine davranılmasını istediği şekilde davranma, diğer insanların } \\
\text { kişiliklerine değer verme; muhatabının konumunu, özelliklerini ve durumunu gözetme, ... }\end{array}$ \\
\hline Sevgi & $\begin{array}{l}\text { Uygun şekilde sevgisini ifade etme, fedakârlık yapma, güven duyma, merhametli olma, aile birliğine } \\
\text { önem verme, diğerkâm olma, vefalı olma, ... }\end{array}$ \\
\hline Vatanseverlik & $\begin{array}{l}\text { Çalışkan ve üretken olma, dayanışma, kurallara ve kanunlara uyma, sadık olma, tarihsel ve doğal } \\
\text { mirasa duyarlı olma, toplumu önemseme, katılımcı olma, ... }\end{array}$ \\
\hline Yardımseverlik & $\begin{array}{l}\text { Cömert olma, iş birliği yapma, merhametli olma, misafirperver olma, paylaşma, dayanışma içinde } \\
\text { bulunma, destek sunma, ... }\end{array}$ \\
\hline
\end{tabular}

Bu çalışmada incelenen "değerin gücü", kitaplarda değerlere ne düzeyde yer verildiğini ifade etmektedir. Kitaplarda değerler, her zaman bir bağlam içinde gerekli vurgu yapılarak işlenmemektedir. Bazı durumlarda sadece ilgili değerin adına veya görseline vurgu yapılarak geçilmektedir. Dolayısıyla değere yer verilme düzeyi, ilgili değerlerin kitaplarda ele alınış şeklini yansıtmakta olup bu çalışmada; zayıf, orta, güçlü olarak nitelendirilmiştir. Bu anlamda, değerlerin gücü belirlenirken araştırmacılar tarafından özgün olarak oluşturulan Tablo 3'teki göstergeler göz önünde bulundurulmuştur.

Tablo 3. Değerlerin Gücünü Belirlemede Dikkat Edilen Göstergeler

\begin{tabular}{ll}
\hline Değerin Gücü & Göstergeler \\
\hline Zayıf & $\begin{array}{l}\text { Değere ilişkili tutum ve davranışlara sadece kelime, görsel ya da sembol bazında yer } \\
\text { verilmiş. }\end{array}$ \\
Orta & $\begin{array}{l}\text { Değerle ilişkili tutum ve davranışlar bir cümle içinde anlamına uygun biçimde kullanılmış. } \\
\text { Güçlü }\end{array}$ \\
\hline
\end{tabular}

\section{Geçerlilik ve Güvenirlilik}

Araştırmada geçerliği sağlamak adına araştırma probleminin seçilmesi, geliştirilmesi ve araştırma bulgularının tartışılması aşamalarında ilgili alan yazından yararlanılmıştır. Geçerliği artırmak için ders 
kitapları amaçsal örnekleme yöntemi ile seçilmiş ve bulgular ders kitaplarından doğrudan alıntılar yapılarak desteklenmiştir.

Araştırmanın güvenirliğini sağlamak için ortaöğretim dokuzuncu sınıf matematik ders kitaplarının her biri dört araştırmacı arasında eşit oranda paylaşılarak her bir bölüm ikişer araştırmacı tarafından ayrı ayrı incelenmiş ve sonuçlar tüm araştırmacılar tarafından birlikte değerlendirilmiştir. Elde edilen kodlamalar arasında "görüş birliği" ve "görüş ayrıllı̆ı" olan durumların sayısı belirlendikten sonra Miles ve Huberman'ın (1994) önerdiği güvenirlik formülü kullanılarak güvenirlik hesaplanmıştır:

\section{Güvenirlik = Görüş Birliği / (Görüş Birliği + Görüş Ayrilığı)}

Güvenirlik değerlerinin \%70'in üzerinde olması araştırma için güvenilir kabul edilmektedir (Miles ve Huberman, 1994). Bu çalışmada da güvenirlik yüzdesi \% 88,2 olarak bulunmuştur. Çalışmada güvenirliğin tespiti için kullanılan formül neticesinde kodlayıcılar arasında \%11,8 oranında görüş ayrılığının yaşandığı belirlenmiştir. Bunun üzerine araştırmacılar görüş ayrılığının nedenlerinin tespiti için birlikte bir değerlendirme yapmışlardır. Neticede görüş ayrılığına sebep olan iki durum olduğu belirlenmiştir:

1. Kodlayıcılardan biri diğer kodlayıcının belirlediği değeri tespit etmemiştir.

2. Bazı kodlamalarda kodlayıcılar tespit ettikleri aynı değer için farklı güçlük düzeyi belirlemişlerdir.

Birinci durumda kodlayıcının değeri tespit ettiği örnek ve kodlama ölçütü üzerinden araştırmacıların birlikte tekrar bir değerlendirme yapmışlardır. Neticede kodlayıcının değeri ve yer verilme düzeyini doğru olarak tespit ettiği ortak görüş olarak ortaya çıkmış ve diğer kodlayıcının örneği gözden kaçırdığı anlaşılmıştır.

İkinci durumda yaşanan görüş ayrılı̆̆ı için araştırmacılar yine örnekler üzerinde birlikte bir değerlendirme yapmışlardır. Değerin ilgili bölümde güçlüğüne ilişkin düzeyin belirlenmesi için Tablo 3'te ortaya konan ölçütlere göre tüm araştırmacılar yeniden düzey tespiti yapmışlar ve çoğunluk olarak ortaya çıkan görüş düzey olarak kodlanmıştır. Tablo 1'de her iki durum için de örnekler yer almaktadır.

\section{Bulgular}

Araştırmanın bu bölümünde dokuzuncu sınıf ortaöğretim matematik ders kitaplarında yer alan kök değerlerin öğrenme alanları / alt öğrenme alanları, kitapta yer aldığı bölüm ve değerin gücüne ilişkin yer alma sıklıkları tablolar hâlinde verilmiştir. Ayrıca bulguların sunulmasında her iki kitap için detaylı bilgilere yer verilmiştir.

Tablo 4'te dokuzuncu sınıf ortaöğretim matematik ders kitaplarında yer alan kök değerlerin görülme sıklığına ve bu kök değerlerin öğrenme alanı / alt öğrenme alanına göre dağılımına yer verilmiştir.

Tablo 4. Ortaöğretim Dokuzuncu Sınıf Matematik Ders Kitaplarında Yer Alan Değerlerin Öğrenme Alanı / Alt Öğrenme Alanına İlişkin Sıklık Tablosu

\begin{tabular}{|c|c|c|c|c|c|c|c|c|c|c|c|c|c|}
\hline $\begin{array}{l}\text { Öğrenme } \\
\text { Alanı }\end{array}$ & $\begin{array}{l}\text { Alt Öğrenme } \\
\text { Alanı }\end{array}$ & Kitaplar & $\frac{\frac{\pi}{\pi}}{\frac{\pi}{d}}$ & $\begin{array}{l}\text { 当 } \\
\text { 苟 } \\
\text { ○ }\end{array}$ & 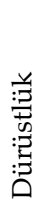 & 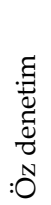 & 光 & $\overrightarrow{\tilde{D}}^{\overrightarrow{00}}$ & $\begin{array}{l}50 \\
\overrightarrow{0} \\
\omega\end{array}$ & 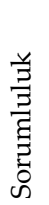 & 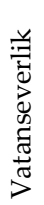 & 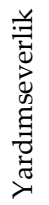 & Toplam \\
\hline \multirow{6}{*}{$\begin{array}{l}\text { Sayılar } \\
\text { Cebir }\end{array}$} & \multirow{2}{*}{ Mantık } & A & - & - & - & - & - & 1 & - & - & 1 & - & 2 \\
\hline & & B & - & - & 1 & - & - & - & - & 1 & 1 & - & 3 \\
\hline & \multirow{2}{*}{ Kümeler } & A & 1 & 1 & 2 & - & 1 & 2 & 1 & - & - & 3 & 11 \\
\hline & & B & - & - & - & - & - & - & - & - & - & - & 0 \\
\hline & \multirow{2}{*}{$\begin{array}{l}\text { Denklem ve } \\
\text { Eşitsizlikler }\end{array}$} & A & - & - & - & - & - & - & - & 2 & - & 4 & 6 \\
\hline & & $\mathrm{B}$ & - & 3 & - & - & 1 & 1 & 2 & 1 & 1 & 3 & 12 \\
\hline \multirow{2}{*}{ Geometri } & \multirow{2}{*}{ Üçgenler } & A & 2 & - & - & - & - & - & - & 1 & 2 & 1 & 6 \\
\hline & & $\mathrm{B}$ & - & - & - & - & - & - & - & - & 1 & - & 1 \\
\hline Veri, Sayma & Veri & $\mathrm{A}$ & - & - & - & 1 & - & - & - & 1 & - & 2 & 4 \\
\hline
\end{tabular}




\begin{tabular}{lcccccccccccc}
\hline ve Olasilik & B & 1 & - & - & 1 & - & - & - & 5 & 1 & 1 & $\mathbf{9}$ \\
\hline & TOPLAM & $\mathbf{4}$ & $\mathbf{4}$ & $\mathbf{3}$ & $\mathbf{2}$ & $\mathbf{2}$ & $\mathbf{4}$ & $\mathbf{3}$ & $\mathbf{1 1}$ & $\mathbf{7}$ & $\mathbf{1 4}$ & $\mathbf{5 4}$ \\
\hline
\end{tabular}

Tablo 4'te görüldüğü gibi, dokuzuncu sınıf ortaöğretim matematik ders kitaplarında en fazla yardımseverlik (14), sorumluluk (11) ve vatanseverlik (7) değerlerine ilişkin ögelere yer verildiği görülmektedir. Öğeleri en az verilen değerler ise özdenetim (2), sabır (2), dürüstlük (3), sevgi (3) ve bunları adalet (4), dostluk (4) ve sayg1 (4) takip etmektedir. Her iki yayınevine ait ders kitabı incelendiğinde iki kitapta da birbirine yakın sayıda değerlere yer verildiği görülmektedir. Ancak A yayınevine ait matematik ders kitabında (29), B yayınevine ait ders kitabına (25) göre daha fazla değere yer verildiği tespit edilmiştir.

Öğrenme alanları açısından değerlendirildiğinde ise incelenen ders kitaplarında değere ilişkin en fazla öge "Sayılar ve Cebir" (34) öğrenme alanında daha sonra "Veri, Sayma ve Olasılık" (13) ve değere ilişkin en az ögeye ise "Geometri" (7) öğrenme alanında yer verildiği görülmüştür. Alt öğrenme alanlarına göre ise incelenen ders kitaplarında değere ilişkin en fazla ögeye "Denklem ve Eşitsizlikler" (18) daha sonra "Veri" (13), "Kümeler" (11), "Üçgenler" (7) ve en az da "Mantık" (5) alt öğrenme alanlarında yer verildiği belirlenmiştir. Buna göre öğrenme alanları ve alt öğrenme alanlarına göre değerlere ilişkin ögelere yer verilme sıklığı açısından dengeli bir dağılımın olmadığı tespit edilmiştir. Yine benzer şekilde öğrenme ve alt öğrenme alanlarına göre değerlere ilişkin ögelerin dağılımının, incelenen iki kitapta da dengeli olmadığı görülmüştür. Örneğin A yayınevine ait kitapta "Kümeler" alt öğrenme alanında değerlere ait ögeye 11 kez yer verilirken, B yayınevine ait kitapta bu alt öğrenme alanında herhangi bir değere ait ögeye yer verilmemiştir.

Tablo 5'de ise dokuzuncu sınıf ortaöğretim matematik ders kitaplarında yer aldığı bölüme göre değerlere hangi sıklıkta yer verildiği gösterilmiştir.

Tablo 5. Ortä̈̆retim Dokuzuncu Sınıf Matematik Ders Kitaplarında Yer Alan Değerlere İlişkin Ögelerin Kitapta Yer Aldığı Bölüme Ait Sıklık Tablosu

\begin{tabular}{|c|c|c|c|c|c|c|c|c|c|c|c|c|}
\hline $\begin{array}{l}\text { Kitapta Yer Aldığ } \\
\text { Bölüm }\end{array}$ & Kitaplar & $\frac{\frac{\pi}{\pi}}{\frac{\pi}{4}}$ & 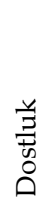 & 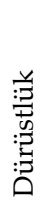 & 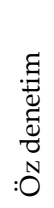 & $\begin{array}{l}\sharp \\
\text { त्र } \\
\text { ल }\end{array}$ & $\begin{array}{l}\overrightarrow{0.0} \\
\stackrel{\vec{J}}{\omega}\end{array}$ & $\begin{array}{l}50 \\
\overrightarrow{0} \\
\text { ஸे }\end{array}$ & 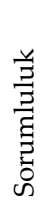 & 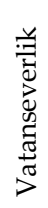 & 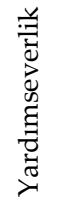 & Toplam \\
\hline \multirow{2}{*}{ Giriş Bölümü } & $\mathrm{A}$ & 2 & 1 & 1 & - & 1 & 1 & - & - & 3 & 2 & 11 \\
\hline & $\mathrm{B}$ & - & - & - & - & - & - & - & 1 & 1 & 1 & 3 \\
\hline \multirow{2}{*}{ Bilgi Kutusu } & $\mathrm{A}$ & - & - & - & - & - & - & - & - & - & - & 0 \\
\hline & $\mathrm{B}$ & - & - & - & - & - & - & - & 2 & - & - & 2 \\
\hline \multirow{2}{*}{ Örnek } & $\mathrm{A}$ & - & - & 1 & 1 & - & - & 1 & 4 & - & 3 & 10 \\
\hline & $\mathrm{B}$ & 1 & 2 & 1 & - & - & - & 2 & 3 & 1 & 3 & 13 \\
\hline \multirow{2}{*}{ Alıştırma } & $\mathrm{A}$ & 1 & - & - & - & - & 2 & - & - & - & 4 & 7 \\
\hline & B & - & 1 & - & - & - & - & - & - & - & - & 1 \\
\hline \multirow{2}{*}{$\begin{array}{c}\text { Değerlendirme } \\
\text { Sorusu }\end{array}$} & $\mathrm{A}$ & - & - & - & - & - & - & - & - & - & 1 & 1 \\
\hline & $\mathrm{B}$ & - & - & - & 1 & 1 & 1 & - & 1 & 2 & - & 6 \\
\hline \multicolumn{2}{|l|}{ TOPLAM } & 4 & 4 & 3 & 2 & 2 & 4 & 3 & 11 & 7 & $\begin{array}{l}1 \\
4\end{array}$ & 54 \\
\hline
\end{tabular}

Tablo 5 incelendiğinde ders kitaplarında yer aldığı bölüme göre değerlere ilişkin ögelerin en fazla örnek (23) daha sonra giriş bölümünde (14) yer verildiği, en az ise sirasiyla bilgi kutusu (2), değerlendirme sorusu (7) ve alı̧̧ırma (8) bölümünde yer verildiği tespit edilmiştir. Her iki yayınevine ait ders kitapları, değerlere ilişkin ögelerin kitapta yer aldığı bölüm açısından ayrı ayrı incelediğinde örnek bölümüne A yayınevine ait kitapta (10) ve B yayınevine ait kitapta (13) dengeli bir şekilde yer verildiği tespit edilmiştir. Kitaplarda yer alan diğer bölümlerde değerlere ilişkin ögelere yer verilme sıklıkları açısından dengeli bir dağılım bulunmamaktadır. Örneğin alıştırma bölümünde A yayınevine ait kitapta (7) B yayınevine ait kitaba (1) göre daha fazla sıklıkta değere rastlanırken, değerlendirme sorusu bölümünde ise A yayınevine ait kitapta (1) B yayınevine ait kitaba göre (6) daha az sıklıkta değere ilişkin ögelere rastlanmıştır.

Aşağıda ders kitaplarının bölümlerinde tespit edilen değerlere ilişkin ögelerden bazılarına örnekler 
verilmiştir. İlk olarak giriş bölümünde yer alan saygı değerine ilişkin örneğe yer verilmiştir.

\section{Giriş Bölümünde Yer Verilen Saygı Değeri ile İlgili Örnek}

\section{Bîr Kümeniin Tümlleyeni}

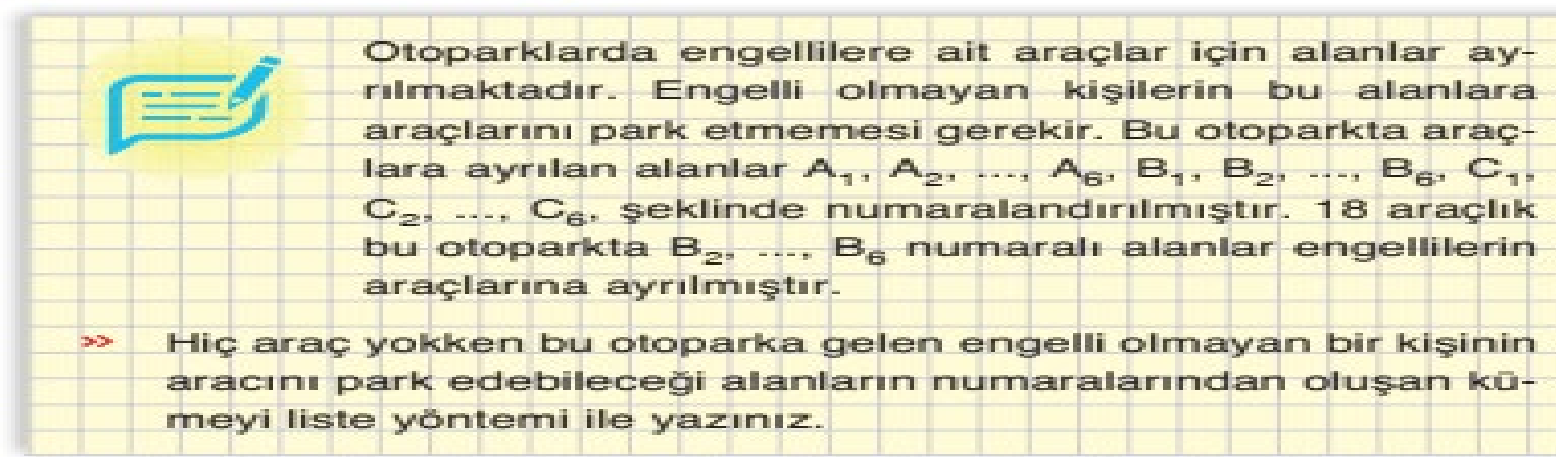

Şekil 1. Dokuzuncu sınıf A yayınevine ait ortaöğretim matematik ders kitabından sayg1 değerine ilişkin giriş bölümü

Şekil 1'deki bir kümenin tümleyeni kavramının işlendiği giriş bölümünde muhatabının konumunu, özelliklerini ve durumunu gözetme davranışı ile saygı değerine ilişkin bir örneğe yer verilmiştir. Giriş bölümünde, otoparklarda engellilerin hayatlarını kolaylaştırmak için araçlarını park edebilecekleri alanlar ayrıldığı ve engelli olmayan kişilerin saygı göstererek bu alanlara araçlarını park etmemeleri gerektiği vurgusu yapılmıştır.

\section{Alıştırma Bölümünde Yer Verilen Yardımseverlik Değeri ile İlgili Örnek}

16. Reyhan Hanım, şapka örūp satarak aile ekonomisine katkıda bulunmak istiyor. Şapka modelleri için 30 TL ye bir dergi alıyor. Öreceği bir şapka için malzeme giderinin 5 TL olacağını hesaplayıp satış fiyatını 20 TL olarak belirliyor.

Bu şapkaların satışından en az 270 TL kâr etmek isteyen Reyhan Hanım en az kaç şapka satmalıdır?

Şekil 2. Dokuzuncu sınıf a yayınevine ait matematik ders kitabından yardımseverlik değerine ilişkin alıştırma

Şekil 2'de verilen alıştırmada dayanışma içinde bulunma ve destek sunma davranışı ile yardımseverlik kök değerine ilişkin bir alıştırmaya yer verilmiştir. Reyhan Hanım şapka örüp satarak aile ekonomisine katkı sunmaktadır. En az kaç şapka satarak kâr edeceğinin bulunmasının istendiği bu alıştırmada aile içerisinde dayanışmaya ve bireylerin birbirine destek sunmasına vurgu yapılmıştır.

\section{Bilgi Kutusu Bölümünde Yer Verilen Sorumluluk Değeri ile İlgili Örnek}

Şekil 3'teki bilgi kutusunda kişinin çeoresine ve vatanına karşı sorumlu olma davranışı ile sorumluluk kök değerine ilişkin bir ögeye yer verilmiştir. Tasarruflu ampullerin daha az elektrik tüketmesi ile ilgili açıklamalar yapılmıştır. Tasarruflu ampullerin hem uzun ömürlü olması hem de daha az elektrik tüketmesi nedeniyle tercih edilmesi teşvik edilmiştir.

\section{Örnek Bölümünde Yer Verilen Dürüstlük Değeri ile İlgili Örnek}

\section{ÖRNEK 34}

İki arkadaş izledikleri bir voleybol maçı dönüşünde Ali ile karşılaşıyor.

- Bir voleybol maçında iki farklı sonuç vardır.

- Ali bu arkadaşlardan birinin doğru bir davranış olmamasına rağmen daima yalan, diğerinin ise erdemli bir şekilde daima doğruyu söylediğini bilmektedir.

- Ali hangi arkadaşının doğru hangi arkadaşının yalan söylediğini unutmuştur.

- Ali bu arkadaşlarından yalnız birine sadece bir soru soracaktır.

Buna göre Ali’nin maçı hangi takımın kazandığını öğrenmesi için sorması gereken soruyu bulunuz.

Şekil 4. Dokuzuncu sınıf B yayınevine ait ortaöğretim matematik ders kitabından dürüstlük değerine ilişkin örnek 
Şekil 4'te verilen örnekte dürüstlük kök değeri doğru sözlü olma davranışına ait bir ögeyle yer verilmiştir. Ali'nin maçı hangi takımın kazandığını öğrenmesi için sorması gereken soru örneğinde yalan söylemenin doğru bir davranış olmadığı doğru söylemenin her zaman erdemli bir davranış olduğu ön plana çıkarılmıştır.

\section{Değerlendirme Sorusu Bölümünde Yer Verilen Öz-denetim Değeri ile İlgili Örnek}

6. Su tasarrufu ile ilgili aşağıdaki bilgiler verilmiştir.

- Diş fırçalarken musluk sürekli açık tutulmazsa kişi başı yılda ortalama 12 ton,

- Duş süresi 1 dakika azaltılırsa kişi başı yılda ortalama 18 ton,

- 4 kişilik bir ailede bulaşıkve çamaşırlar makinede yıkanırsayılda ortalama 40 ton,

- 4 kişilik bir ailede sebze ve meyveler çeşme altında değil de su dolu bir kapta yıkanırsa yılda ortalama 18 ton su tasarrufu yapılabilmektedir. Bu bilgilere göre 4 kişilik bir ailenin her bireyi, yukarıdaki tedbirleri uygulamaya başlıyor. 1 ton suyun 2,5 Türk lirası olduğu bir şehirde bu ailenin bir yıl içerisinde kaç Türk lirası tasarruf edebileceğini hesaplayıp verilen her maddeye göre elde edilen yıllık tasarruf tutarını Türk lirası cinsinden sütun grafiği ile gösteriniz.

Şekil 5. Dokuzuncu sınıf B yayınevine ait ortaöğretim matematik ders kitabından öz denetim değerine ilişkin değerlendirme sorusu

Şekil 5'te verilen değerlendirme sorusunda davranışlarını kontrol etme davranışı ile öz-denetim değerine ait bir ögeye yer verilmiştir. Burada 4 kişilik bir aile bireylerinin davranışlarını kontrol ederek yani su tasarrufuna ilişkin farklı tedbirler uygulayarak bu davranışları sonucunda bir yıl içerisinde kaç Türk lirası tasarruf edebileceklerini hesaplamalarıyla öz denetim değerine vurgu yapılmışır.

Tablo 6'da ise ortaöğretim dokuzuncu sınıf matematik ders kitaplarındaki kök değerlere hangi güçlükte ve hangi sıklıkta yer verildiği gösterilmiştir.

Tablo 6. Ortaöğretim Dokuzuncu Sımı Matematik Ders Kitaplarında Yer Alan Kök Değerlerin Gücüne Ait Sıklı Tablosu

\begin{tabular}{|c|c|c|c|c|c|c|c|c|c|c|c|c|}
\hline Değerin Gücü & Kitaplar & $\frac{\frac{\vec{d}}{\pi}}{\frac{\pi}{\frac{\pi}{4}}}$ & 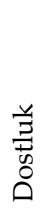 & 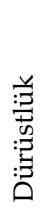 & 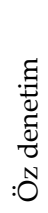 & 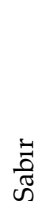 & 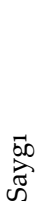 & $\begin{array}{l}500 \\
\vec{\nu} \\
\infty\end{array}$ & 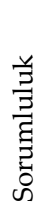 & 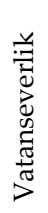 & 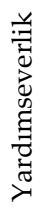 & Toplam \\
\hline \multirow{2}{*}{ Zayif } & $\mathrm{A}$ & 3 & 1 & 2 & - & 1 & 2 & 1 & 2 & 3 & 5 & 20 \\
\hline & $\mathrm{B}$ & 1 & 2 & - & - & - & - & - & 3 & 3 & 1 & 10 \\
\hline \multirow{2}{*}{ Orta } & $\mathrm{A}$ & - & - & - & - & - & - & - & 1 & - & 2 & 3 \\
\hline & $\mathrm{B}$ & - & 1 & - & - & 1 & 1 & 2 & 3 & - & 3 & 11 \\
\hline \multirow{3}{*}{ Güçlü } & $\mathrm{A}$ & - & - & - & 1 & - & 1 & - & 1 & - & 3 & 6 \\
\hline & $\mathrm{B}$ & - & - & 1 & 1 & - & - & - & 1 & 1 & - & 4 \\
\hline & TOPLAM & 4 & 4 & 3 & 2 & 2 & 4 & 3 & 11 & 7 & 14 & 54 \\
\hline
\end{tabular}

Tablo 6 incelendiğinde yer verme sıklığı açısından değerlere ilişkin ögelere en fazla zayıf düzeyde (30), daha sonra orta düzeyde (14) ve en az güçlü düzeyde (10) yer verildiği tespit edilmiştir. Her iki yayınevine ait ders kitapları, yer verilen ögelerdeki değerlerin gücü açısından incelendiğinde gerek A yayınevine ait kitapta gerekse de B yayınevine ait kitapta değerlere ilişkin ögelere farklı güçlükte yer verme sıklı̆̆ı açısından dengeli bir dağılım bulunmadığı görülmüştür. Örneğin zayıf güçlükteki değerlere ilişkin ögelere A yayınevine ait kitapta (20), B yayınevine ait kitaba (10) göre daha fazla sıklıkta yer verilmiştir. Ayrıca ders kitaplarında ögelere ilişkin değerlere güçlü düzeyde yeterince yer verilmediği söylenebilir.

Aşağıda ders kitaplarında yer alan vatanseverlik, sevgi ve adalet kök değerlerine ilişkin ögeler farklı güçlükte birer örnekle sunulmuştur. 
Vatanseverlik Değerinin Güçlü Bir Şekilde Verilmesine İlişkin Örnek

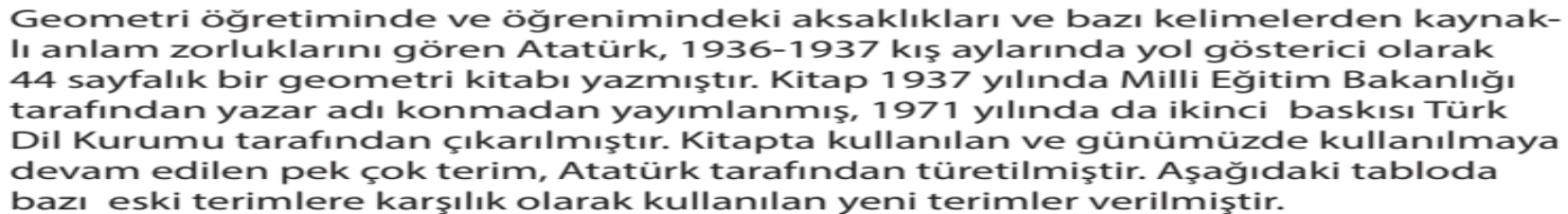
bazı eski terimlere karşılık olarak kullanılan yeni terimler verilmiştir.

\begin{tabular}{|l|l|}
\hline Eski & Yeni \\
\hline Zaviye & Açı \\
\hline Dılı & Kenar \\
\hline Zaviye-i Hadde & Dar Açı \\
\hline Hattı Munassıf & Açıortay \\
\hline Mustatil & Dikdörtgen \\
\hline Musavi & Eşit \\
\hline Hat & Çizgi \\
\hline Re's & Köşe \\
\hline Murabba & Kare \\
\hline
\end{tabular}

Şekil 6. Dokuzuncu sınıf B yayınevine ait ortaöğretim matematik ders kitabından vatanseverlik değerinin güçlü bir şekilde verilmesi

Şekil 6'da vatanseverlik değerine ilişkin çalı̧kan ve üretken olma ve toplumu önemseme davranışları ile güçlü bir şekilde vurgulanmıştır. Geometri öğretiminde ve öğreniminde yaşanan aksaklıklar ve bazı kelimelerden kaynaklanan zorluklar nedeniyle Atatürk, eski terimlere karşıllk gelen yeni terimlerin içinde bulunduğu 44 sayfalık geometri kitabı yazmıştır. Değerin güçlü bir şekilde verilmesi için değere ilişkin davranışın bir bağlam içerisinde anlamına uygun şekilde ve önemi açıç̧a vurgulanmalıdır. Atatürk'ün bu davranışı (çalışması) geometrinin öğrenilmesini/öğretilmesini kolaylaştırma noktasında sağladığı yarar açıkça vurgulanmıştır ve önemi belirtilmiştir. Atatürk, Türk milletine yol gösterme amacıyla yazdığı geometri kitabının yazar adı konulmaksızın yayınlanmasını istemiştir. Burada yol gösterme amacı ve yazar adı olmaksızın kitabın yayınlanması vatanseverlik değerinin anlamına uygun şekilde verilmiştir.

Sabır Değerinin Orta Güçlükte Verilmesine İlişkin Örnek

\section{Düzenli antreman yaparak azim ve sabırla spor müsabakalarına hazırlanan Ferdi, ilk gün bir miktar yol koştuktan sonra her gün bir önceki günden 3 km fazla koşmuştur. Bir haftada toplam 77 km koştuğuna göre ilk gün kaç kilometre yol koşmuştur?}
A) 1
B) 2
C) 3
D) 4
E) 5

Şekil 7. Dokuzuncu Sınıf B Yayınevine Ait Ortaöğretim Matematik Ders Kitabından Sabır Değerinin Orta Güçlükte Verilmesi

Şekil 7'de verilen örnekte sabır değerine ilişkin davranış azimli olma ve dirençli olmayla vurgulanmıştır. Azim ve sabırla düzenli olarak antrenman yapma ifade edilmiştir. Değerin orta güçlükte verilmesinde ilgili değerle ilişkili tutum ve davranışlar bir cümle içinde anlamına uygun biçimde kullanılmalıdır. Burada azim ve sabır davranışı bir bağlam içerisinde ifade edilmiş ancak davranışın işlevi ya da önemi hakkında bir bilgi verilmemiştir. Bir başka deyişle düzenli antrenman yapmanın sonucunda elde ettiği başarı ifade edilmiş olsa idi azim ve sabır değeri güçlü bir şekilde verilmiş olurdu. 
Adalet Değerinin Zayıf Güçlükte Verilmesine İlişkin Örnek

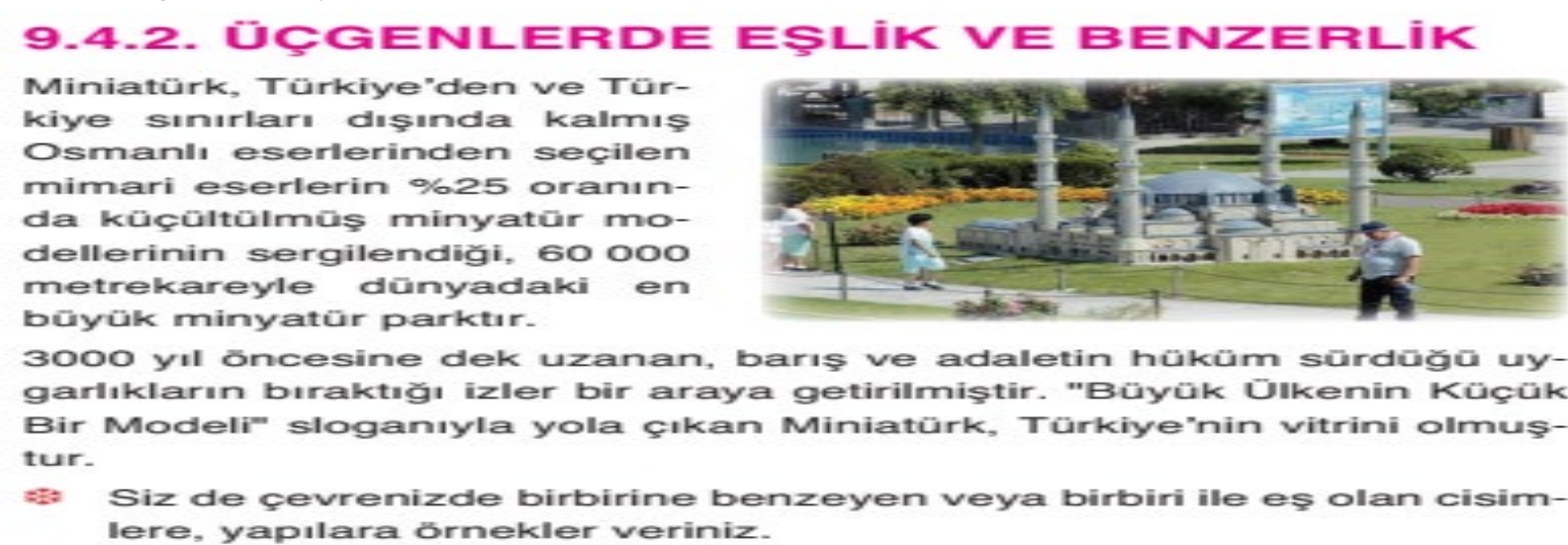

Şekil 8. Dokuzuncu sınıf B yayınevine ait ortaöğretim matematik ders kitabından adalet değerinin zayıf bir şekilde verilmesi

Şekil 8'de verilen giriş bölümünde adalet değerine ilişkin bir davranış olan adil olma zayıf şekilde ele alınmıştır. Değerin zayıf düzeyde vurgulanması için değerle ilişkili tutum ve davranışlara sadece kelime, görsel ya da sembol bazında yer verilmiş olmalıdır. Giriş kısmında Miniatürk ile ilgili özelliklerden bahsedilirken "3000 yıl öncesine dek uzanan, barış ve adaletin hüküm sürdüğ̈̈ uygarlıklar..." ifadesi kullanılarak adalet değerine ilişkin ögeye yer verilmiştir. İlgili bölümde adalet değerine ilişkin ifadeye sadece bir cümle içerisinde yer verilmiş ancak adalet değeri ile ilgili herhangi bir açıklama yapılmamıştır.

\section{Sonuç ve Tartışma}

Araştırmanın sonucunda 9. sınıf ortaöğretim matematik ders kitaplarında en çok yardımseverlik ve sorumluluk değerlerine yer verildiği belirlenmiştir. Bunun nedeni olarak da matematik dersinin yardımseverlik, sorumluluk ve adalet değerleriyle ilişkili olması gösterilebilir. Özellikle matematik dersi kazanımları ile birlikte paylaşma, kendisine ve çevresine karşı sorumlu olma, eşit davranma, kurallara uyma, dayanışma içinde olma gibi davranışların aktarımın daha kolay olduğu düşünülmektedir. Alan yazın incelendiğinde ise bu çalı̧̧manın sonuçlarıyla benzer veya farklı sonuçların elde edildiği çalışmalara rastlanmıştır. Sayın ve diğerleri (2019) yaptıkları çalışma sonunda 5. sınıf matematik ders kitabında en çok yer alan değerlerin sırasıyla öz denetim, adalet, yardımseverlik ve sorumluluk değeri olduğunu belirlemişlerdir. Kılcan (2020) tarafından yürütülen araştırmada da ortaokul matematik ders kitaplarında en çok rastlanılan kök değerlerin sırasıyla sorumluluk, sevgi, yardımseverlik ve adalet olduğu görülmüştür. Bunun yanında Şahin ve Tuğrul (2020) ilkokul matematik ders kitaplarında en fazla yer alan sosyal değerlerin sevgi ve yardımlaşma olduğunu tespit etmiştir. Yine Şahin ve Başgül (2018) yaptıkları çalışma sonucunda ortaokul matematik ders kitaplarında en fazla yer alan sosyal değerlerin sırasıyla; sorumluluk, evrenselcilik, sevgi ve yardımlaşma olduğunu ifade etmişlerdir. Diğer taraftan Şahin ve Başgül'ün araştırmalarının sonucunda en fazla yer verilen değerler arasında olan evrenselcilik değeri MEB (2018) tarafından açıklanan kök değerler arasında yer almadığından bu araştırmada incelenen değerler arasında yer almamaktadır. Öte yandan Karaca ve Uzunkol (2019) ise üçüncü ve dördüncü sınıf matematik ders kitaplarında en az yer verilen değerlerin sorumluluk ve yardımseverlik olduğunu tespit etmişlerdir. Bu nedenle bu sonuç ile bu çalışmada elde edilen sonuç örtüşmemektedir. Buna ek olarak Karaca ve Uzunkol araştırmalarında üçüncü ve dördüncü sinıf matematik ders kitaplarında en çok yer verilen değerin tutumluluk olduğunu tespit etmişlerdir. Ancak tutumluluk değeri de MEB (2018) tarafından açıklanan kök değerler arasında yer almadığından bu araştırmada incelenen değerler arasında değildir.

Araştırmanın sonunda elde edilen bir başka sonuç ise 9. sınıf ortaöğretim matematik ders kitaplarında en az rastlanılan değerlerin sabır, öz denetim, dürüstlük ve sevgi olmasıdır. Burada özellikle sabır ve öz denetim değerlerinin matematik ders kitaplarında en az rastlanılan değerler arasında olması dikkat çekmektedir. Çünkü ünlü matematikçilerin hayatlarından örnekler verilerek azimli olma, davranışlarını kontrol etme, tahammül etme gibi davranışların aktarılabileceği düşünülmektedir. Bunun yanında dürüstlük ve sevgi 
değerleri matematik kazanımları ile doğrudan ilişkilendirilmese de matematik problemleri içerisinde bu değerlere ve önemlerine daha fazla vurgu yapılabileceği söylenilebilir. İlgili çalışmalar incelendiğinde ise bu çalışmanın sonuçlarıyla benzer veya farklı sonuçların elde edildiği görülmüştür. Sayın ve diğerleri (2019) 5 . sınıf matematik ders kitabında en az değinilen değerlerin saygı, sevgi, dostluk, dürüstlük ve vatanseverlik değerleri olduğunu, sabır değerine ise kitapta hiç değinilmediğini belirtmişlerdir. Buna karşın Sayın ve diğerleri çalışmalarında 5. sınıf matematik ders kitabında en çok yer alan değerler arasında öz denetim değerinin olduğunu da tespit etmişlerdir. Buradan Sayın ve diğerlerinin (2019) elde ettikleri sonuç ile bu çalışmanın sonuçlarının farklılık gösterdiği görülmüştür. Karaca ve Uzunkol (2019) üçüncü ve dördüncü sınıf matematik ders kitaplarında öz denetim, saygı, sevgi, sorumluluk, yardımseverlik değerlerine az da olsa yer verildiğini ancak sabır, adalet, dostluk ve dürüstlük değerlerine hiç yer verilmediğini belirlemişlerdir. Kılcan (2020) araştırmasında ortaokul matematik ders kitaplarında dürüstlük ve saygı değerlerinin en az sayıda yer verilen kök değerler olduğunu belirtmiştir. Öte yandan Kılcan (2020) araştırmasında ortaokul matematik ders kitaplarında en çok rastlanılan değerler arasında sevgi değerinin olduğunu tespit etmiştir. Benzer şekilde Şahin ve Başgül (2018) ortaokul, Şahin ve Tuğrul (2020) da ilkokul matematik ders kitaplarında en fazla yer alan değerler arasında sevgi değerinin olduğu sonucuna ulaşmışlardır. Bu nedenle bu sonuçlar, bu araştırmada elde edilen sonuçlarla örtüşmemektedir.

Görüldüğü gibi bu çalışmada da benzer çalışmalarda da matematik ders kitaplarında bazı değerlere daha az bazılarına ise daha çok yer verildiği tespit edilmiştir. Ancak bu durumun 2018 yılında yenilenen matematik dersi öğretim programında belirtilen kök değerlerin tamamının öğrencilere kazandırılmasında yeterli olmadığı düşünülmektedir. Bu nedenle kök değerlerin ders kitaplarındaki dağılımının daha dengeli olması önem taşımaktadır. Bunun yanında bu araştırmada ve daha önce yapılan araştırmalarda, değerlerin matematik ders kitaplarında yer alma sıklıklarının sıralamalarına ilişkin elde edilen sonuçların birbirleriyle farklılık gösterdiği görülmektedir. Bu farklılıkların ilkokul, ortaokul ve lise kademelerindeki kitapların yapılarının farklı olmasından kaynaklandığı düşünülmektedir. Ders kitaplarının sınıf seviyelerinin farklı olması, matematik dersinin farklı sınıf düzeylerine göre ders içeriklerindeki konuların giderek soyutlaşması bu farklılıklara sebep olabilir. Buna ek olarak bu farklılıkların kitap yazarlarının değer algılarının ve önem verdikleri değerlerin farklılık göstermesinden de kaynaklanabileceği düşünülmektedir.

Kök değerlerin 9. sınıf ortaöğretim matematik ders kitaplarındaki öğrenme alanlarına göre yer verilme sıklıkları incelendiğinde en fazla "Sayılar ve Cebir" öğrenme alanında, en az ise "Geometri" öğrenme alanında değerlere yer verildiği sonucuna ulaşılmıştır. Benzer şekilde Sayın ve diğerlerinin (2019) yaptıkları araştırmada 5. sınıf matematik ders kitabında en fazla değere 1. Ünitede (doğal sayılar, doğal sayılarla işlemler, kesirler) yer verildiğini öyle ki bu kitapta tespit edilen değerlerin yarısından fazlasının bu ünitede yer aldığını belirlemişlerdir. Yine araştırmacılar inceledikleri kitapta değerlere en az 3 . Ünitede (temel geometrik kavramlar ve çizimler, üçgenler ve dörtgenler, veri işleme) ve 4 . Ünitede (uzunluk ve zaman ölçme, alan ölçme, geometrik cisimler) yer verildiğini belirtmişlerdir. Şahin ve Başgül (2018) tarafından yapılan çalışmada da ortaokul matematik ders kitaplarında en fazla sosyal değerlere "Sayılar ve İşlemler" öğrenme alanında yer verildiği tespit edilmiştir. Yine Şahin ve Tuğrul (2020) ilkokul matematik ders kitaplarında tüm sınıf düzeylerinde değerlere en fazla "Sayılar ve İşlemler" öğrenme alanında yer verildiği sonucuna ulaşmıştır. Ancak bu iki çalışmada da değerlere en az "Veri İşleme" öğrenme alanında yer verildiği tespit edilmiştir. Bu nedenle bu araştırmada elde edilen sonuç ile farklılık göstermektedir. Bunlara ek olarak bu çalışmada karşılaştırılan iki farklı yayınevine ait 9. sınıf ortaöğretim matematik ders kitaplarının öğrenme/alt öğrenme alanlarına göre değerlere yer verme sıklıklarının farklılık gösterdiği belirlenmiştir. Ayrıca bu kitaplarda bazı alt öğrenme alanlarının ele alındığı bölümlerde değerlere daha çok yer verildiği bazılarında ise ya çok az yer verildiği ya da hiç yer verilmediği tespit edilmiştir. Buradan matematik ders kitaplarında değerlerin öğrenme alanlarına göre dağılımının dengeli olmadığı görülmektedir. Ancak değerlerin kazandırılmasında değerlerin her öğrenme alanına eşit sıklıkta dağıtılmasının daha etkili olacağı düşünülmektedir. Nitekim öğretim programlarında da değerler eğitiminin öğretim programlarının yalnız bir birimiyle (öğrenme alanının, ünite, konu vb.) sınırlı tutulmamasına dikkat edilmesi vurgulanmıştır (MEB, 2018). 
$\mathrm{Bu}$ araştırmanın sonunda kitapların bölümlerine göre kök değerlere en çok örneklerde yer verildiği daha sonra ise sırasıyla giriş bölümünde, alıştırmalarda, değerlendirmede ve bilgi kutusunda rastlanıldığ1 belirlenmiştir. Karaca ve Uzunkol (2019) değerlerin üçüncü ve dördüncü sınıf matematik ders kitaplarındaki birimlere göre yer alma sıklıklarını incelediklerinde; değerlerin en çok çalışmalarda $(\% 35,1)$ daha sonra sirasiyla problemlerde $(\% 29,8)$, örneklerde $(\% 19,3)$, değerlendirmede $(\% 10,5)$ ve etkinliklerde $(\% 5,3)$ yer verildiğini tespit etmişlerdir. Karaca ve Uzunkol'un (2019) çalışmalarında incelenen kitapların "çalışma" olarak isimlendirdiği bölümün konunun öğrenilip pekiştirilmesi için öğrencilerin yapacağı ek bireysel çalışmalar olarak belirtildiği bu bölümün bu araştırmadaki "alıştırma" bölümü ile örtüştüğü görülmektedir. Yine bu araştırmada incelenen ortaöğretim 9. sınıf matematik kitaplarının problemleri de örnek olarak isimlendirdiği ayrıca bir problem bölümü açmadıkları belirlenmiştir. Bu nedenle Karaca ve Uzunkol'un çalışmalarındaki "problem" ve "örnek" bölümlerinde yer verilen değerlerin yer verilme sıklıkları birleştirildiğinde bu çalışmada elde edilen sonuçla benzerlik gösterdiği söylenebilir. Bu iki çalışmada yer alan "giriş bölümü" ve "etkinlik" bölümlerinin ise tam olarak birbiriyle örtüşmediği görülmüştür. Bu farklılığın nedeni olarak da araştırmalarda incelenen kitapların lise ve ilkokul kitapları olması gösterilebilir. Bunun yanında değerlerin en çok örnekler bölümünde yer verilmesinin kitaplarda yer alan örnek sayısının fazla olmasından kaynaklanabileceği düşünülmektedir.

Araştırmanın sonunda 9. sınıf ortaöğretim matematik ders kitaplarının değerlere yer verme düzeylerinin en fazla zayıf düzeyde, daha sonra orta düzeyde ve en az da güçlü düzeyde olduğu tespit edilmiştir. Dolayısıyla incelenen ders kitaplarında genellikle değeri çağrıştıran yani değerle ilgili unsurlara (görsel, kelime, sembol vb.) yer verildiği ancak değerin bir bağlam içerisinde vurgulanmadığı, değerin önemine ve faydasına ilişkin açıklamaların bulunmadığı görülmüştür. Bu durumun kök değerlerin öğrenciler tarafından benimsenmesi ve hayat tarzına dönüştürülmesi için yeterli olmadığı düşünülmektedir. Nitekim matematik dersi öğretim programında da değerlerin, öğrencilere hissettirilmesi, yaşantısal hâle getirilmesi ve hem aleni hem de örtük bir biçimde kazandırılmaya çalışılması gerektiği vurgulanmıştır (MEB-TTKB, 2017). Bu nedenle değerlerin öğrenciler tarafından içselleştirilmesi için matematik ders kitaplarında değerlerin yalnızca ifadelerine yer verilmesinden daha çok değerlerin öneminin vurgulandığı eyleme dönük etkinliklere yer verilmesinin gerektiği düşünülmektedir.

$\mathrm{Bu}$ araştırmadan elde edilen sonuçlar doğrultusunda MEB (2018) tarafından belirtilen kök değerlerin ortaöğretim 9. sınıf matematik ders kitaplarındaki dağılımının yer verilme sıklığı bakımından dengeli olmadığ1 görülmüştür. Bu nedenle kök değerlerin tamamının öğrencilere kazandırılabilmesi için ders kitaplarında bu değerlere eşit sıklıkla yer verilmesine özen gösterilmesinin önemli olduğu düşünülmektedir. Kitaplarda kök değerlere yer verilme sıklığının dengeli olmayışı bazı değerlerin diğerlerine göre geri planda kalması, bazılarınınsa ön plana çıkması sonucunu doğurmaktadır. Kitaplarda bazı değerlerin diğerlerine göre daha yoğun işlenmiş olması bu değerlerin diğerlerine göre daha önemli olduğu hissiyatı uyandırabilir. Hâlbuki öğretim programlarında yer verilen kök değerler arasında herhangi bir hiyerarşi ya da önem sırası bulunmamaktadır. Bu sebeple ders kitaplardaki mevcut bu durumun değerler eğitimi açısından doğru olmayacağı düşünülmektedir. Buna ek olarak 9. sınıf ortaöğretim matematik ders kitaplarında değerlerin öğrenme alanlarına ve kitaplardaki bölümlere göre de dağılımının dengeli olmadığı tespit edilmiştir. Buradan ders kitabı hazırlama çalışmalarında değerlerin öğrenme alanlarına ve kitapların bölümlerine göre dağılımının dengeli yapılmasına dikkat edilmesi önerilmektedir. Son olarak değerlerin öğretiminde ders kitaplarının etkili bir kaynak olabilmesi için kök değerlerle ilgili tutum ve davranışların ilgili etkinliklerde bir bağlam içerisinde sunulmasının ve değerlerin öneminin vurgulanmasının önemli olduğu düşünülmektedir. Ayrıca ders kitaplarının hazırlanması aşamasında değerler eğitimine yönelik standartların oluşturulması, değerlerin kazandırılmasına katkı sağlaması açısından önemli görülmektedir.

\section{Yazarların Beyanı}

Araştırmacıların katkı oranı beyanı: Verilerin toplanması, analiz edilmesi ve makalenin yazım aşamasında bütün araştırmacılar birlikte çalışmıştır.

Etik Kurul Kararı: Araştırmacılar verilerin toplanmasında, analizinde ve raporlanmasında her türlü etik ilke ve kurala 
sadık kalmışlardır.

Çatışma beyanı: Araştırma sürecinde herhangi bir kişi ya da kurumla çıkar çatışması yaşanmamıştır. Yazarlar arasında herhangi bir çıkar çatışması bulunmamaktadır.

\section{Kaynaklar}

Altun, A. S. (2003). Eğitim yönetimi ve değerler. Değerler Eğitimi Dergisi, 1(1), 7-17.

Bishop, A. J. (1999). Mathematics teaching and values education an intersection in need of research. Zentralblatt für Didaktik der Mathematik, 31, 1-4. https://doi.org/10.1007/s11858-999-0001-2.

Bishop, A., Clarke, B., Corrigan, D. \& Gunstone, D. (2006). Values in mathematics and science education: Researchers' and teachers' views on the similarities and differences. For the Learning of Mathematics, 26(1), 7-11.

Bogdan, R.C. ,\& Biklen, S.K. (1992). Qualitative research for education: An intoduction to theory and methods (2. bs.). Boston: Allyn \& Bacon.

Bolay, S. H. (2007). Değerlerimiz ve günlük hayat. Değerler Eğitimi Dergisi, 1(1), 12-19.

Cao, Z., Seah, W. T., \& Bishop, A. J. (2006). A comparison of mathematical values conveyed in mathematics textbooks in China and Australia. Mathematics education in different cultural traditions-a comparative study of East Asia and the West içinde (ss. 483-493). Springer, Boston, MA.

Clarkson, P. C., FitzSimons, G. E., \& Seah, W. T. (1999). Values relevant to mathematics? I'd like to see that. Mathematics: Across the ages. Melbourne: Mathematics Association of Victoria.

Creswell, J. W. (2012). Educational research: Planning, conducting, and evaluating quantitative and qualitative research (4. bs.) Boston, MA: Pearson.

Dede, Y. (2007). Matematik öğretiminde değerlerin yeri. Abant İzzet Baysal Üniversitesi Eğitim Fakültesi Dergisi, 7(1), 12-25.

Karaca, D., \& Uzunkol, E. (2019). İlkokul matematik ders kitaplarının içerdiği değerler bakımından incelenmesi. Uluslararası Alan Eğitimi Dergisi, 5(2), 55-71.

Kılcan, T. (2020). Ortaokul ve imam hatip ortaokulları matematik ders kitaplarında yer alan kök değerlerin incelenmesi. Uluslararası Sosyal Bilgilerde Yeni Yaklaşımlar Dergisi (IJONASS), 4(2), 247-265.

Mcmillian, H. J., \& Schumacher, S. (2010). Research in education. Boston: Pearson Education.

MEB (2018). Ortaöğretim matematik dersi (9, 10, 11 ve 12. Simflar) öğretim programı. Ankara: Talim ve Terbiye Kurulu.

MEB-TTKB (2018). Lise matematik dersi öğretim programı. Ankara: Milli Eğitim Bakanlığı.

Meydan, H. (2014). Okulda değerler eğitiminin yeri ve değerler eğitimi yaklaşımları üzerine bir değerlendirme. BË̈ İlahiyat Fakültesi Dergisi, 1(1), 93-108.

Miles, M. B., \& Huberman, A.M. (1994). An expanded sourcebook qualitative data analysis (2. bask1). California: Sage Publication.

Milli Eğitim Bakanlığ1-Talim ve Terbiye Kurulu Başkanlığ1 (MEB-TTKB) (2017, Temmuz 18). Müfredatta yenileme ve değişiklik çalışmalarımı üzerine. http://ttkb-dot-meb-dot-gov-dottr.gateway.web.tr/meb_iys_dosyalar/2017_07/18160003_basin_aciklamasi-program.pdf adresinden 10.02.2021 tarihinde alındı.

Neuman, W. L. (2014). Social researceh methods: Qualitative and quantitative approaches (7. bask1). London: Pearson Education.

Özkaya, F., \& Duru, A. (2020). Ortaokul matematik ders kitaplarında değerler eğitimi kapsamındaki 
değerlerin yer alma durumlarının incelenmesi. Uşak Üniversitesi Eğitim Araştırmaları Dergisi, 6(3), 43-67.

Sayın, V., Orbay, K., \& Şam, E. A. (2019). 5. Sınıf matematik ders kitabının değerlerimiz açısından incelenmesi. IBAD Sosyal Bilimler Dergisi, Ekim 2019 Özel Sayısı,161-171. DOI: 10.21733/ibad.605040

Seah, W. T., \& Bishop, A. J. (2000). Values in mathematics textbooks: A view through two Australasian regions. Paper presented at the 81st annual meeting of the American Educational Research Association, New Orleans, LA.

Şahin, Ö., \& Başgül, M. (2018). Ortaokul matematik ders kitaplarında sosyal değerler. Dicle Üniversitesi Ziya Gökalp Ĕ̆itim Fakültesi Dergisi, (34), 90-104.

Şahin, Ö., \& Tuğrul, K. (2020). İlkokul matematik ders kitaplarında sosyal değerler. Değerler Eğitimi Dergisi, 18(39), 173-208.

Şahin, T., \& Ersoy, F. (2012). Sosyal bilgiler ders kitaplarının değerler eğitimi yaklaşımları açısından incelenmesi. Kuram ve Uygulamada Ĕ̆itim Bilimleri Dergisi, 12(2), 1535-1558.

TDK (2020). Güncel Türkçe Sözlük. Web: https://sozluk.gov.tr/ adresinden 01.03.2021 tarihinde alınmıştır.

Topal, Y. (2019). Değerler eğitimi ve on kök değer. Mavi Atlas, 7(1), 245-254.

Ulusoy, K., \& Dilmaç, B. (2012). Değerler eğitimi. Ankara: Pegem Akademi.

Yıldırım, A., \& Şimşek, H. (2016). Sosyal bilimlerde nitel araştırma yöntemleri (10. bs.). Ankara: Seçkin Yayıncılık.

Yin, R. K. (2011). Qualitative research from start to finish. New York: Guilford Press.

\section{İncelenen Ders Kitapları}

Aytar, H. (2019). Ortaöğretim matematik 9 ders kitabı. İstanbul: Eksen Yayıncılık (A).

Maviş, M., Gül, G., Solaklığlu, H., Tarku, H., Bulut, F., \& Gökşen, M. (2019). Ortä̈ğretim matematik 9 ders kitabı. Ankara: Milli Eğitim Bakanlığı (B). 


\section{EXTENDED ABSTRACT}

\section{Introduction}

It is an important that students internalize positive values through the educational activities that they carry out in schools (Altun, 2003). Starting from the idea that values education is one of the main aims of all education, it should be adopted as a basic principle that learning about values should be considered as an integral part of all curricula, not just in one or a few courses. To this end, for the first time, values education has now become part of all curricula, unlike in the past (MEB-TTKB, 2017). Given that helping our students learn about values can only be achieved by taking into account all the elements of an educational program (MEB, 2018), it should not be forgotten that the textbook is one of the most important tools that help students learn about values. In this study, the researchers analyzed the ways in which values were included in secondary school mathematics textbooks, the strength of those values (weak, medium, strong), and how they were distributed between the different sections of the textbooks.

\section{Method}

This research took the form of a case study, which is one of the qualitative research designs. The issues discussed in this research is the "root values" promoted in $9^{\text {th }}$ grade secondary mathematics textbooks. The data source of the research was the textbooks themselves. In selecting the books examined in the study, the criterion sampling method, one of the purposeful sampling methods, was used. Two secondary $9^{\text {th }}$ grade mathematics textbooks, which had been allocated by the Board of Education and Discipline of the Ministry of National Education (MEB, 2018), and which were available at www.eba.gov.tr, were examined.

The data of the research were collected using the document analysis technique. These data were analyzed with the descriptive analysis technique, one of the qualitative data analysis techniques. In order to ensure the validity of the research, the textbooks were selected using the purposive sampling method and the findings were supported by direct quotations from the textbooks.

\section{Result and Discussion}

As a result of the research, it was determined that the values of benevolence and responsibility were most included in the $9^{\text {th }}$ grade secondary mathematics textbooks. The reason for this is that the mathematics course is related to the values of benevolence, responsibility and justice. Another result obtained at the end of the research was that the least common values promoted in the $9^{\text {th }}$-grade secondary mathematics textbooks were patience, self-control, honesty and love. It is noteworthy that patience and self-control were among the least common values promoted in the mathematics textbooks. By giving examples from the lives of famous mathematicians, the textbooks aimed to demonstrate behaviors such as being determined, practicing selfcontrol and being persistent. In similar studies, it has been determined that some values are less frequently promoted, while some are more frequently promoted in mathematics textbooks. However, it is thought that this situation is not sufficient for students to gain all the root values specified in the mathematics curriculum in Turkey, which was renewed in 2018. For this reason, it is important that the distribution of root values discussed in the textbooks be more balanced.

When the frequency with which the root values were promoted according to the learning areas was examined, it was concluded that the values were most frequently discussed in the "Numbers and Algebra" learning area, while they were least frequently discuss in the "Geometry" learning area. From this, it can be seen that the distribution of the discussion of values in mathematics textbooks according to learning areas is imbalanced. The current research determined that the root values were mostly included in the examples given in the book chapters. Following this, they were mostly discussed in the introductory sections, the exercises, the evaluation and specific "information boxes", respectively. Examining the literature, various studies were found with both similar and different results to the results of this study (Karaca ve Uzunkol, 2019; Kılcan, 2020; Sayın et al., 2019; Şahin and Tuğrul, 2020; Şahin and Başgül, 2018).

At the end of the research, it was determined that the values were predominantly included in the textbooks 
examined at a weak level. It was observed that elements related to values (specific images, words, symbols, etc.) were generally included, but that the values themselves were not emphasized in context, and there were no explanations about the importance and benefit of individual values. This situation is not sufficient for students to adopt the root values and apply them in their lives. It has been emphasized that values should be experientially understood by students and that they should learn them both implicitly and explicitly (MEBTTKB, 2017).

The results obtained from this research demonstrated that the distribution of root values specified by the Ministry of National Education (2018) was unbalanced in terms of their presence in $9^{\text {th }}$ grade mathematics textbooks. For this reason, it is important to pay better attention to how well these values are included in the textbooks so that all the core values can be acquired by students. In addition, it was found that the distribution of discussion about values was unbalanced in terms of the learning areas covered by the $9^{\text {th }}$ grade mathematics textbooks. In this regard, it is recommended that more attention be paid to balancing the distribution of values with in different learning areas. Finally, in order for textbooks to be an effective resource in teaching values, it is important to present attitudes and behaviors related to the root values in context during relevant activities and to continue to emphasize the importance of values. In addition, standards for values education should be established during the preparation of textbooks in order to contribute to students' acquisition of values. 